\title{
Marriage Tradition of Tobati Tribe: in Perspective on Islamic Law
}

\section{Eko Siswanto}

Institut Agama Islam Negeri (IAIN) Fattahul Muluk Papua, Indonesia siswantoeko44@yahoo.co.id

\section{A. Ubaidillah}

Institut Agama Islam Negeri (IAIN) Fattahul Muluk Papua, Indonesia aubaidillahmaduri05@gmail.com

\section{Abstract}

This study investigated the marriage has human values to fulfill the instincts of human life. In the community of Tobati tribes, marriage has been arranged based on its customary traditions that have been agreed upon for generations. It focused on exploring the form of the marriage tradition of the repentant tribal people and how Islamic law analyzes the similarities and differences. The researcher applied descriptive qualitative design to explore the objectives of this study then analyzed by Miles Huberman's theory. The findings show that there are several steps in the marriage process, namely: first, propose (ask in marriage); second, waiting for a period (waiting for a decision from the woman's family); third, giving the application, and the last, the procession of the marriage. These four stages, there are similar to the stages of marriage according to Islamic law, but there is a very significant difference, namely the obligation to deliver the application after obtaining approval to carry out the wedding procession.

Keywords: Tobati Tribe, Tradition, Islamic Law. 


\section{Abstrak}

TRADISI PERKAWINAN SUKU TOBATI: PERSPEKTIF HUKUM ISLAM. Perkawinan mempunyai nilai kemanusiaan untuk memenuhi naluri hidup manusia. Pada masyarakat suku Tobati, perkawinan telah diatur berdasarkan tradisi adatnya yang sudah disepakati turuntemurun. Kajian dalam artikel ini lebih memfokuskan pada penelitian bentuk tradisi perkawinan masyarakat suku Tobati dan bagaimana hukum Islam menganalisis persamaan dan perbedaannya dengan menggunakan metode penelitian kualitatif deskriptif yang bertujuan untuk mendeskripsikan hasil temuan lapangan yang dianalisis menggunakan model Miles Huberman. Hasil temuannya bahwa terdapat beberapa langkah dalam proses pernikahan, yaitu: pertama, melamar (peminangan); kedua, masa penantian (menunggu jawaban dari pihak keluarga perempuan); ketiga, memberikan hantaran lamaran; keempat, pelaksanaan pernikahan. Dari empat tahapan ini terdapat kemiripan dengan tahapan perkawinan menurut hukum Islam. Namun demikian, ada perbedaan yang sangat signifikan, yaitu kewajiban dalam memberikan hantaran setelah mendapatkan persetujuan untuk dilaksanakannya prosesi pernikahan.

Kata Kunci: Suku Tobati, Adat, Hukum Islam.

\section{A. Introduction}

Marriage is a sacred covenant that is expected for married couples to gain happiness in living together. According to Marriage Law No. 1 of 1974 stated that marriage is an inner birth bond between a man and a woman to live a happy and eternal home based on the one true Godhead. ${ }^{1}$

Marriage has human values to fulfill human life instincts to preserve offspring, realize peace of life, and foster compassion in people's lives. ${ }^{2}$ Marriage is one of the pillars of community life that can not be separated from a series of traditional events and ceremonies of certain tribes that they adhere to, either before, while, or after the marriage ceremony is carried out.

\footnotetext{
${ }^{1}$ Undang-undang Nomor 1 Tahun 1974 Tentang Perkawinan, Pasal 1.

${ }^{2}$ H.S.A. al-Hamdani, Risalah Nikah Hukum Perkawinan Islam (Jakarta: Pustaka Amani, 1989), 23.
} 
In general, the implementation of traditional marriage ceremonies in Indonesia is influenced by the form and system of local customary marriage concerning the arrangement of the community or family maintained by the community concerned. ${ }^{3}$ This can be proven by previous research, i.e.:

First, the journal was written by Fahmi Kamal with the title "Javanese Traditional Marriage in Indonesian Culture" published by Jurnal Pariwisata dan Budaya, University of Bina Sarana Informatics, Faculty of Economics and Business in 2014. This journal explained that the form of Javanese traditional marriage is a part of Indonesian culture. At the same time in this journal contains cultural diversity and customs especially related to marriage that applies locally. This is because the cultural products of certain communities can not be forced to be enforced against other regions. ${ }^{4}$

Second, the journal was written by Bayu Ady Pratama, the University of Sebelas Maret with the title "Javanese Traditional Marriage in Nengah Village, Bayat District, Klaten Regency". In this journal, the implementation of Javanese traditional wedding ceremony is the legacy of Keraton Surakarta and Yogyakarta. Wedding ceremonies in Javanese culture adhere to the standard rules. These rules and procedures not only show aesthetic value but also carry a philosophical meaning. ${ }^{5}$

Third, a journal was written by Debora Maria Paramita Pasaribu with the title "Development of Batak Toba Traditional Marriage System in Medan". This journal was published by Diponegoro Law Journal in 2017. The journal explained that the development of the mating system that occurs is the development of the exogamous mating system into eleuthrogami. This can be seen from the occurrence of inter-clan marriages in the Batak Toba community. ${ }^{6}$

${ }^{3}$ Hilman Hadikusuma, Hukum Perkawinan Indonesia Menurut Pandangan Hukum Adat, Hukum Agama (Bandung: Mandar Maju, 1990), 97.

${ }^{4}$ Fahmi Kamal, "Perkawinan Adat Jawa dalam Kebudayaan Indonesia", Jurnal Pariwisata dan Budaya 5, no. 2 (2014).

${ }^{5}$ Bayu Ady Pratama, "Pernikahan Adat Jawa di Desa Nengahan Kecamatan Bayat Kabupaten Klaten", Jurnal Haluan Sastra Budaya 2, no. (2018).

${ }^{6}$ Debora Maria Paramita Pasaribu, "Perkembangan Sistem Perkawinan Adat Batak Toba di Kota Medan", Diponegoro Law Journal 6, no. 2 (2017). 
Although the research above has similarities in terms of traditional marriage, some differences focus more on cultural aspects analyzed through the perspective of Islamic law on equality and differences. Religion, including Islam, has completely regulated something related to marriage. As a form of contract or transaction that results in the rights and obligations between the relevant parties, namely married couples.

Based on direct observations made by the author that in the traditional marriage Tobati tribe has also been arranged in full on matters related to marriage, ranging from asking, waiting for answers, asking for answers, delivering applications, to the wedding procession takes place. This system has been long-lasting and maintained by the local community as evidenced by the dowry obtained from its generations.

Tobati tribe is one of the tribes in Kampung Tobati and Kampung Enggros Jayapura City (Tobati-Enggros) as local indigenous people who became the first inhabitants of this area close to the country of Papua New Guinea. Aside from the Tobati tribe, there are also Kayu Batu, Nafri, Skouw, and Sentani tribes who are indigenous Papuans who inhabit the Jayapura City.

Basically, from the observations above the author argues that the tradition of marriage Tobati tribe does not deviate much from the thought of Islamic law. So, the author considers it important to know the form of the marriage tradition of the Tobati tribe and how Islamic law sees it will be disproved.

\section{B. Discussion}

\section{Description of Tobati Tribe Region}

In Jayapura City, there is a Tobati Tribe (Tobati-Enggros people) as local indigenous people who became the first inhabitants of this area close to the country of Papua New Guinea. Apart from the Tobati tribe, there are Kayu Batu, Nafri, Skouw, and Sentani tribes who are indigenous Papuans who inhabit the Jayapura City. Not far from Jayapura City center, about 20 minutes to Abepura 
subdistrict of Jayapura, there is a bay called Youtefa Bay. There are two villages namely Tobati and Enggros villages, which have long inhabited the area.

Tobati tribe or also called Tobati-Enggros (some refer to Youtefa Tobati) is one of the indigenous Indonesian tribes living in Papua province. The Tobati tribe who inhabit the Youtefa Bay Coast covering an area of 1,675 h.a. which is included in the South Jayapura Sub-District, Jayapura Municipality, has built settlements on seawater. Until now, Tobati settlements around Youtefa Bay, Jayapura, are generally built on sea level which is precisely built close to land.

For the Tobati tribe who lives on water areas, the main mode of transportation for the community is boats. The locals call it "Wah" which means boat. Residents in Tobati and Enggros village have made Wah as a means of public transportation and also as transportation to catch fish. Previously, to run Wah had to use oars, but in its development, automatic machines have been used to facilitate travel using Wah. If previously the travel time to a place reached 30 minutes but currently, the trip only takes about 4 minutes using the machine. ${ }^{7}$

\section{Form of Tobati Marriage}

\section{a. Propose (Applying)}

Before marriage, some conditions must be met from both the male and the female side, here are the conditions: through representatives. In the Tobati marriage tradition, the procession of applying is carried out by the male party represented to other tribes that have been appointed or through representation. The representative is not from the family or from the tribe itself but must be from another tribe that is trusted. The selection of family representatives in the procession proposes some conditions have been set

${ }^{7}$ WWW.kabarpapua.co, accessed April 4, 2019. 
by the elders, namely certain tribes that are allowed to be representatives in the procession.

Starting from proposing (asking a daughter). Representatives of the men's families will come to the women to ask if their daughter is married or not or has been proposed to by another man. Then the representative conveyed the intention to ask the girl if the girl has not chosen ties with other parties. The term used by the local community is to come to ask for girls.

In this proposal, it is required for women not to have ties with others, meaning that they are not being proposed to other men or married. To find out that the status of the girl of the Tobati tribe, it is usually indicated by the term thorny and thornless sago tree/leaf. Thorny Sago means it already has ties to other men, while Thornyless Sago meaning girls have no ties to other men.

In Kompilasi Hukum Islam (KHI, the Compilation of Islamic Law) Article 1, Chapter 1, Letter a, gives the understanding that the proposing is an effort towards the occurrence of a matchmaking relationship between a man and a woman that can be done by a person who wants to find a partner but can also be done by a trustworthy intermediary. But in practice, the dreaming can be done blatantly against women who are still alone. If the marriage to a woman who is still in the period of 'iddah wafat or 'iddah talak ba'in is done with kinayah (satire) to respect the woman's feelings. ${ }^{8}$ In this case, the application becomes a preparatory step to the marriage prescribed by Allah swt. Before the implementation of the marriage contract, to further increase their knowledge, the couple's marriage knows about their respective dispositions, behaviors, and tendencies of each other in the hope of entering the future marital life with a stronger heart and feelings. Thus, the marriage can be said as a request or

${ }^{8}$ Cik Hasan Bisri, Kompilasi Hukum Islam dan Peradilan Agama dalam Sistem Hukum Nasional (Jakarta: Logos, 1999), 139. 
statement from a man to a woman by the customs that apply in the area either sharih (blatant) or kinayah (innuendo) that can be done alone or through intermediaries. ${ }^{9}$

From some of the above opinions, it can be concluded that propose (khitbah) is the process of request or statement to hold a marriage conducted by two people, male and female, either directly or by guardianship. Application (khitbah) is done before the wedding ceremony is held.

As for the legal basis for proposing, in Q.S. al-Baqarah [2]: 235 becomes the basis of the marriage, which reads, "There is no $\sin$ for you to propose to these women with sarcasm or you to hide (the desire to marry them) in your heart. Allah knows that you will mention them, in which you do not make a marriage vow to them in secret, except just saying (to them) unreasonable words. And do not carry out (remained) an act of marriage, before her 'iddah runs out, and know that Allah knows what is in your heart. Then fear Him (Allah), and know that Allah is Forgiving and Forbearing." Rasulullah saw. said, "If one of you proposes a woman, then if you can see something that will encourage him to marry her, then you should do it."10

In Indonesia, it is regulated in Kompilasi Hukum Islam (KHI, the Compilation of Islamic Law) in Article 1 states that the proposal is the request of a man to a wife or person in charge to be married to the woman. ${ }^{11}$ The provisions related to it are mentioned in articles 11, 12, and 13. Article 11: Marriage can be carried out directly by a person who wants to find a mate but can also be done by a trusted intermediary. Article 12: (1) The transfer can be done to a virgin woman or to a widow who has expired her 'iddah; (2) Women who are bullied by their husbands who are still in the 'iddah raj'iah haram and forbidden to be loaned; (3) It is also forbidden to

\footnotetext{
${ }^{9}$ M. Baqir al-Habsyi, Fikih Praktis (Bandung: Mizan, 2002), 42.

${ }^{10}$ M. Mahdil Mawahib, Fiqih Munakahah (Kediri: STAIN Kediri, 2009), 11.

${ }^{11}$ Abdul Ghani Abdulloh, Pengantar Kompilasi Hukum Islam dalam Tata Hukum Nasional (Jakarta: Gema Insani Press, 1994), 77.
} 
ask for a woman who is being loaned by another man, as long as the man's proposal has not been broken up or there has been no rejection on the part of the woman; (4) Breaking up with the men because of statements about the breakup of the proposed relationship or secretly the man who asked to have stayed away and left the woman on loan.

The dreaming of someone who has been loaned by others, the scholars agreed that the dreaming of a person against someone who has been loaned is haram. Ijma'scholars say that the second incarnation, which came after the first proposal, is not allowed. This happens when: the woman pleased with the man who asked and agreed to the proposal clearly (sharahah) or gave permission to his guardian to accept the proposal; the second proposal came not with the permission of the first proposal; the first applicant has not canceled the proposal. ${ }^{12}$

These provisions apply so that no one feels hurt to each other. As for the imperfect proposal, with the understanding still waiting for answers, some scholars differ opinions. Hanafiah stated that a proposal to someone who is confused in making a decision is makruh. This is contrary to the opinion of some scholars who say that the act is not unlawful. This opinion is based on Fatimah binti Qais proposed by three people at once, namely Mu'awiyah, Abu Jahim bin Huzafah, and Usamah bin Zaid. This happened after the completion of Fatimah's 'iddah period which had been rejected by Abu Umar bin Hafsin. Nevertheless, Hanafi's opinion is stronger because it is Islamic behavior that teaches solidarity. The marriage that is done to someone who is confused in considering the decision has more impact on breaking the relationship between the first applicant and will disturb the psychology of the applicant. ${ }^{13}$

${ }^{12}$ Amir Syarifuddin, Hukum Perkawinan Islam di Indonesia: antara Fiqih Munahakat dan Undang-undang Perkawinan (Jakarta: Kencana Prenada Media Group, 2009), 53.

${ }^{13}$ Wahbah az-Zuhaili, Fiqh al-Islami wa Adillatuhu (Beirut: Dar al-Fikr, n.d.), 7: 11. 
Proposing marriage is one of the efforts made with the aim of the relationship between a man and a woman delivered by the man to the woman's family. Related to the proposing marriage, that the Tobati people prohibited a woman who was or has been loaned by another man. This is in line with Islamic law, that the cleric agreed that the treatment of a person against someone who has been loaned is unlawful. The ijma' of scholars said that the second incarnation, which came after the first proposal, is not allowed. In the hadith of the Prophet Muhammad saw. it is also explained, "Lest someone from you propose to the (woman) who was proposed by his brother so that the previous suitor left him or has allowed it" (H.R. Muttafaq 'Alaih).

The explanation above shows that proposing marriage in the Tobati tradition has similarities with Kompilasi Hukum Islam (KHI, the Compilation of Islamic Law). But in practice, there is little difference between the two, that the tradition of the Tobati tribe scents the presence of representatives from the male side in the delivery of the marriage purpose, while there is no provision on the matter in Kompilasi Hukum Islam (KHI, the Compilation of Islamic Law).

\section{b. Waiting Period for Answers}

After conveying the purpose of the arrival, the representative will resign or the proposed family will allow the applicant to return one week later to return to get an answer. Within a week the parents of the women will hand over the verdict to the daughter proposed to accept or reject the application, there is no coercion on the part of the family to their daughter in choosing a life partner.

\section{c. Delivery of Application}

After getting an answer from the woman's family, if the answer is rejected then the marriage is annulled or no marriage occurs. However, if accepted, the next procession is to bring 
an application to the women's family. Delivery of applications for the Tobati tribe must be in the form of beads made of special stone. Every family of the tribe in Papua, especially the Tobati tribe usually has the bead stone, where the bead stone or bead is a legacy of the ancestors that will always be maintained as one of the family's wealth. The requirement to apply in the Tobati tribe must carry two black and yellow bead stones. Especially for Chief's (Ondoafi) children as a condition of delivery of applications in addition to beads coupled with stone bracelets. Where the bracelet is derived from the family's ancestral heritage as well as the beads.

Conduct in the view of Islamic law is not obligatory, and if it is fulfilled the law is permissible as long as it is by the ability or not burdensome. In contrast to the dowry that has been regulated in Islamic law. This delivery is in principle according to Islam is a gift or something given to honor the family that is visited or aims to give more pleasure to the family of the prospective spouse.

Although the delivery is not ruled or not mandatory, the law is mubah (permissible). Because in the context of mu'amalah (Islamic economic law), something that is not prohibited is given the category of permissive law. We can see a fiqh rule that mentions "al-ashlu fi al-asyya al-ibahah hatta yadulla ad-dalilu 'ala tahrimiha" which means it is permissible as long as there is no evidence against it. Thus, giving this delivery is allowed and not prohibited in Islam, but if it is not done, it does not cause sin and the marriage that will be held remains valid even if there is no delivery. There are several delivery conditions if you still want to pay for it: delivery is not mandatory, only in the form of the law of receiving gifts in Islam or besides; delivery may be given according to ability and the male or female parties should not burden each other or ask for excessive delivery; delivery is given to please not to show off or to be arrogant; delivery is given with money that is halal with the principle of money 
management in Islam and with halal goods, it is forbidden to send in the form of illicit goods or from debt, because it is a form of coercion on one's own.

In the custom of Egyptian society, the goods are included in the dowry, because the public agreed to the delivery ahead of the wedding reception. So, the delivery of goods or tradition of delivery is not only in Indonesia, but also abroad. Therefore, the delivery item comes out of the status as a regular gift and becomes a special gift that must be given in a marriage called a dowry. In Islamic law, it is stated that 'urf (habit) that is not contrary to the teachings of religion can be a recognized proof of syara'. This is according to the word of Allah swt., "Be forgiving and have people do the ma'ruf" (Q.S. al-A'raf [7]: 199).

Narrated from Ibnu Mas'ud ra., he said, "What is considered by the Muslims as a good thing, then it is good according to Allah swt. and what is considered by the Muslims an evil, then it is ugly according to Allah swt." (H.R. Ahmad and ath-Thayalisi). So, the delivery item is part of the dowry which is considered to be important and included in the marriage. On the other hand, the status of the woman is not yet the wife of the man, so she is not entitled to any dowry. A woman becomes entitled to half the dowry with the marriage contract, and she is entitled to the entire dowry if she has been cared for by her husband. Thus, the goods given by the men to the women belong to the men, if one or both parties cancel the engagement contract. The women are not entitled to the goods. This law applies regardless of who canceled the engagement, whether it was a male or a female family. As for the other gifts, he was likened to a grant. Based on The Law of the State of Egypt No. 1 of 2000 which refers to the opinion of madzhab Hanafi, it is stated that: "Grants can be taken back if the form and specifications are intact."

Dowry is mandatory, and delivery is not an obligation and only as a gift. Syekh Muhammad bin Shalih al-Utsaymin 
said, "The dowry that is prescribed is a little dowry, even less is more important, it is to exemplify the noble Prophet and to get the blessing of marriage because the most blessed marriage is the lightest dowry." Imam Muslim narrates in his Sahih no. 1425: That a friend once said to the Prophet, "I was about to marry a woman, so the Prophet asked, how much is the dowry?" He answered four uqiyah (160 dirhams), the Prophet (peace and blessings of Allah be upon him) said four uqiyah? As if you were sculpting silver from the mountain." Imam an-Nawawi said in Syarh Sahih Muslim 9/553, "So his word is to hate from expensive dowry to the husband, we can not give you anything, but hopefully we can give it away another time." Umar bin Khattab r.a. also said, "Do not allow the dowry, if it can glorify you in the world and the hereafter, indeed the Prophet (peace and blessings of Allah be upon him) is the most entitled to do so. Indeed, he did not give dowries to his wives, nor did any of his daughters be given a dowry of more than 12 uqiyah" (Irwa al-Ghalil, no. 1927).

At this point, there is a significant difference, in the tradition of marriage Tobati tribe oblige the delivery of applications from the male side after getting a "Yes" answer from the women in the form of beads (family inheritance). And, for the chief's son plus a stone bracelet. This is a sign of social status.

According to the point of view of Islamic law, delivery marriage is not mandatory, if implemented then it becomes mubah. But in principle, it has a purpose to respect and give pleasure to the family that comes.

\section{d. Marriage Procession}

\section{1) Marriage Age Requirements}

The requirement to marry a Tobati woman is approximately 28 years old. This is done because according to their belief women must be physically strong to be a wife and mother. One of them is characterized 
by the age that has reached 28 years and the waist circumference of women.

The results of the observations above are in line with the provisions of the age limit expressed in article 15 paragraph (1) of Kompilalasi Hukum Islam (the Compilation of Islamic Law, HKI) based on consideration of the benefit of family and marital households. This is in line with the emphasis on the Marriage Law, that a husband-and-wife candidate must have their soul and body matured so that they can realize the goal of marriage well without ending in divorce and having good and healthy offspring. Therefore, marriages performed by prospective underage brides should be refused to reduce the occurrence of divorce as a result of their disloyal rights and obligations as husband and wife. ${ }^{14}$

The provisions of Law No. 1 of 1974 concerning the marriage age limit above have changed as stipulated in Law of the Republic of Indonesia No. 16 of 2019 concerning Amendment to Law No. 1 of 1974 concerning marriage which states that the minimum age of marriage for women is equal to the minimum age of marriage for men, which is 19 years.

The determination of age in the form of Indonesian style of ijtihad (Indonesian style of fiqh) is a manifestation in the renewal of fiqh that develops (before the existence of the marriage law). However, when reviewed by sources, rules, and principles that are used as a benchmark for determining the age limit (a solid foundation). ${ }^{15}$ For example, the word of Allah swt. in Q.S. an-Nisa' [4]: 9 as follows, means: "And do fear Allah those who should leave behind them weak children, whom they worry about (their welfare). Therefore, let them fear Allah, and let them speak the right word" (Q.S. an-Nisa' [4]: 9). 13-14.

${ }^{14}$ Zainuddin Ali, Hukum Perdata Islam di Indonesia (Jakarta: Sinar Grafika, 2006), ${ }^{15} \mathrm{Ali}, 14$. 
The content of the above paragraph is general, does not directly indicate that marriage is carried out by a young spouse (under the provisions stipulated by Law No. 1 of 1974) will produce offspring that are feared for his welfare. However, based on the facts in divorce cases in Indonesia conducted by young couples, more things are not in line with the vision and mission of marriage goals, namely the creation of peace in the household based on love and affection (mawadah wa rahmah). The purpose of marriage will be difficult to realize if the maturity of the soul and body of the bride and groom in entering the marriage is not fulfilled. ${ }^{16}$

When using the methodology approach in the assessment of Islamic law (fiqh) on the determination of the age of marriage, it is necessary to consider the method of problem mursalah (ijtihad method in Islamic law based on general benefit). However, such methods at certain times and places give dispensation in certain cases.

The determination of the age limit of a marriage of women in the Tobati tribe has the same purpose as Islamic law, that the determination of age is based on the benefit of the family, where women must have a strong physical, mature soul to realize the purpose of marriage.

According to Tobati tribal beliefs, women aged 28 already have a strong physique and a mature soul. This is similar to the emphasis of marriage law that husband and wife must have cooked their soul to realize marriage well without ending in divorce. It's just that the age limit determined by the Tobatu tribal community is well above the minimum age limit of the marriage law which states that the age limit of men is 19 years while the female age limit is 16 years.

The explanation above has a similar purpose in determining the age limit of marriage for women. 


\section{2) Dowry}

There is one term known from the Tobati tribe namely Night Payment (Sitting Fee). The wedding procession begins with the arrival of women to the men and the entire family of women from all generations of women and above who are still alive. In this procession, there is a habit of the Tobati community giving money (sitting fee) to the whole family of women from the generation of women. This procession is called Pembayaran Malam (Night Payment). Night payments can be given to half of the women's families present, the remaining night payments will be given after giving birth to the couple's first child.

Based on the above observations, there are similarities with the explanation of Q.S. an-Nisa' [4]: 4, "And give the dowry as a willing gift" (Q.S. an-Nisa' [4]: 4). In Article 32 of Kompilasi Hukum Islam (the Compilation of Islamic Law, KHI), it is stated that "The dowry is given directly to the bride and has since become her right". Basically, the dowry is not a condition of the marriage contract but is a semi-binding gift that must be given to the wife before the husband and wife relationship, even if the agreed dowry is not yet fully agreed upon.

In terminology according to Imam Taqiyuddin Abu Bakr, the dowry is a property given to a woman from a man when married or having sex (wathi'). ${ }^{17}$ According to H.S.A. al-Hamdani, a dowry is the gift of a husband to his wife before, after, or during the marriage contract as a compulsory gift that cannot be replaced by anything else. ${ }^{18}$

${ }^{17}$ Imam Taqiyuddin Abu Bakar bin Muhammad al-Hussaini, Kifayah al-Akhyar (Beirut: Dar al-Kutub al-'Ilmiyah, n.d.), 2: 60.

${ }^{18}$ H.S.A. al-Hamdani, Risalah Nikah Hukum Perkawinan Islam (Jakarta: Pustaka Amani, 1989), 110. 
According to Syekh Zainuddin bin Abdul Aziz al-Malibari al-Fanani, defining dowry is some assets that must be given because of marriage or wathi' (intercourse). Dowry is called shadaq because it contains an understanding as an expression of honesty of the giver's interest in doing marriage, while marriage is the basis for requiring a dowry. ${ }^{19}$ Scholars of the fiqh of sect observers give definitions with formulations that do not differ substantially. ${ }^{20}$ As follows: the Mazhab Hanafi (in part) defines that the dowry is a required property of the husband during the marriage contract in return for the sexual pleasure he receives. ${ }^{21}$ The Mazhab Maliki defines: "Dowry is as a thing that makes the wife lawful to be hunted". According to the sect, the wife is allowed to refuse to be re-married before receiving her dowry, even though there has been prior intercourse. The Mazhab Hanbali states that dowry is "in exchange for a marriage, whether clearly stated in the marriage contract, determined after the agreement of both parties, and determined by a judge". Mazhab Syafi'i defines dowry as something that must be paid due to marriage or intercourse. ${ }^{22}$

According to Kompilasi Hukum Islam (the Compilation of Islamic Law, KHI), a dowry is defined as a gift from the groom to the bride, whether in the form of goods, money, or services that are not contrary to Islamic law. ${ }^{23}$ And in Article 32 of (the Compilation of Islamic Law, KHI), it is stated that "The dowry is given directly

\footnotetext{
${ }^{19}$ Zainuddin bin Abdul Aziz al-Malibari al-Fanani, Fath al-Mu'in (Semarang: Toha Putra, n.d.), 70.

${ }^{20}$ Teungku Muhammad Hasbi ash-Shiddieqy, Hukum-hukum Fiqih Islam: Tinjauan Antar Mazhab (Semarang: P.T. Pustaka Rizki Putra, 2001), 254.

${ }^{21}$ Amir Syarifuddin, Hukum Perkawinan Islam di Indonesia: antara Fiqih Munahakat dan Undang-undang Perkawinan (Jakarta: Kencana Prenada Media Group, 2009), 85.

${ }^{22}$ Abdul Azis Dahlan, Ensiklopedi Hukum Islam (Jakarta: P.T. Intermasa, 2003), 1042.

${ }^{23}$ Direktori Pembinaan Badan Peradilan Agama Islam Departemen Agama RI, Kompilasi Hukum di Indonesia (Jakarta: Direktori Pembinaan Badan Peradilan Agama Islam Departemen Agama RI, 2001), 1.
} 
to the bride and has since become her right". The dowry is not a condition of the marriage contract, but it is a gift that is semi-binding, which the husband must give to the wife before the husband and wife relationship, even if the agreed dowry is not yet fully agreed upon. ${ }^{24}$

The dowry given to the prospective wife must meet the following conditions: the property or property is valuable. Unauthorized dowry with worthless property or object, although there is no provision for many or at least dowry. However, if the dowry is little but valuable then the marriage is still valid. The goods are sacred and can be taken advantage of. Therefore, it is not permissible to give dowries with wine, pigs, and blood and carrion, therefore it has no value according to the view of Islamic shari'a. It is haram and worthless. Mahar is not a ghasab item. Ghasab means to take someone else's property without his permission but does not intend to own it because he will return it later. Giving dowry with various ghosob results is not valid. Must be replaced with a dowry, but the marriage contract is still valid. The dowry must not be in the form of an unknown shape, type, and nature. ${ }^{25}$

The wisdom of dowry is as follows: showing the glory of women. It's the woman who's looking, not looking for it and the one looking for it is a man; to show the love and affection of a husband for his wife so that the gift of the property is nothing of her, namely as gifts and grants not as payment for the price of the woman; as a symbol of seriousness. The giving of this wealth shows that men are seriously intending to women, earnest in dealing with them; that Islam puts the responsibility of the family in the hands of men (husbands) because their natural ability in controlling emotions (feelings) greater

${ }^{24} \mathrm{Abdul}$ Azis Dahlan, Ensiklopedi Hukum Islam (Jakarta: P.T. Intermasa, 2003), 1043.

${ }^{25} \mathrm{Abd}$. Rahman Ghazaly, Fiqih Munakahat: Seri Buku Daras (Jakarta: Prenada Media, 2003), 87-88. 
than women. Man is better able to manage their lives together, therefore it is only natural that men who pay the dowry because he has such rights, and on the other hand he will be more responsible and not arbitrarily destroy the household just because of trivial problems. ${ }^{26}$

As for the issue of dowry, Islamic law considers that there are similarities in the giving of dowry to women. It is characterized by the same goal, which is to equally appreciate women. Besides, the dowry can be paid equally as long as it has no descendants.

But there is little difference in the issue of designation. In Islamic law, the dowry is given to the bride, while in the tradition of the tobati tribe, the dowry (Night Payment/Sitting Fee) is given to the whole family of women from all generations and above who are still alive and participate in their arrival to the male side. This is a sign of appreciation to the women. Basically, from the description above, there is no significant difference in the issue of dowry.

\section{3) Purpose of Marriage}

In the Tobati tribe, one of the purposes of marriage is to have descendants to pass on the generations of their tribe. If the married woman has no children, there are two consequences: (a) the women's family refunded the night payment; (b) the sister let go of the sister/sister married the party to get offspring. Women who are unable to give offspring may or may not be divorced, depending on the behavior/nature of the woman in the family. For example, whether she is a calm/ patient woman and good at taking care of the household or a woman who is grumpy or has a bad nature in the family. The presence of both parties at the evening payment event as a sign of consent and legal marriage.

${ }^{26}$ Yusuf al-Qaradhawi, Fatwa-fatwa Kontemporer (Jakarta: Gema Insani Press, 1995), 2: 478. 
Islam explains that the purpose of marriage: (a) To meet the demands of human instincts that are human nature is human nature, then the legal way to meet this need is by marriage agreement (through marriage level), not in a fraudulent way and violate religion such as living together without being married, prostitutes, adultery, lesbians, homos, and so forth that have been distorted and forbidden by Islam; (b) To fortify the noble character and to subjugate the gaze. The main objectives of marriage prescribed in Islam include fortifying human dignity from evil and heinous acts, which can degrade and undermine the dignity of a noble human being. Islam views marriage and family formation as an effective means of nurturing youth and young people from harm and protecting society from chaos. Rasulullah saw. said, "Youth! And, whosoever of you can marry, then marry there is more subjugated and more fortifying of the genitals (farji). And whosoever is unable to do so, let him fast"; (c) To establish an Islamic household. In the Qur'an it is stated that Islam justifies the existence of thalaq (divorce), if the husband and wife are no longer able to enforce the limits of Allah, as the word of Allah swt., "Thalaq can be referred to twice. After that, the husband can hold well or let go well. It is not halal for you to take back something that you have given them, except both (husband and wife) are fearful of not being able to carry out the laws of Allah. But if you (wali) fear that they will not be able to keep the law of Allah, then there is no sin upon them if they (must) pay what they have been given (by the wife) to ransom themselves. That is the rulings of Allah, so do not violate it. Whoever violates Allah's laws, they are the wrongdoers" (Q.S. al-Baqarah [2]: 229). That is, both have been unable to carry out the sharia of Allah Swt.

It is permitted to refer if they can enforce the bounds of Allah. As mentioned in Surah al-Baqarah, continued the above verse: "Then if he (husband) divorces her 
(after the second divorce), then that woman is no longer lawful for him before he marries another husband. If the other husband divorces her, then there is no sin for both (the first husband and the former wife) to remarry if both think that they will be able to carry out Allah's laws. These are the provisions of Allah which explains to those who are knowledgeable" (Q.S. al-Baqarah [2]: 230). Thus, the noble purpose of marriage is for husband and wife to carry out Islamic shari'a in their household. The law of enforcing the household based on Islamic shari'a is mandatory. Therefore, every Muslim and Muslimah who wants to build an Islamic household.

Islamic law sees that the purpose of marriage in the tobati tribe has something in common, namely, aiming to have offspring for the sake of the continuity of the family and tribe and can form a good nature for both brides. However, there is little difference with the view of Islamic law, that for women who cannot give offspring, men have the right to divorce them, while in Islamic law there is no desire for divorce even though religion allows it. The presence of two parties at the night payment ceremony is a sign of approval and validity of the marriage.

\section{Conclusion}

There are several marriage traditions of the Tobati tribe, which include: conditions that must be met both from the male and female parties when applying must go through representatives who are not from the family or from the tribe itself but must be from other trusted tribes. The selection of family representatives in the procession of applying some conditions have been set by the elders: certain tribes are allowed to be representatives in the procession of applying; for Tobati women must be approximately 28 years old; propose (asking for a daughter) the male party's family representative will come to the woman's side to ask whether their daughter is married or not or has been proposed by another male; 
waiting period (waiting for answers from the women's family); delivery of applications for the Tobati tribe must be in the form of beads made of special stone. At the time of the wedding procession (married), there is a Night Payment (Sitting Fee) to the entire family of women from the generation of women. Tobati marriage tradition when analyzed the similarities and differences seen from the point of view of Islamic law there are some similarities, there are only differences in the point of delivery of the application. 


\section{REFERENCES}

Abdulloh, Abdul Ghani. Pengantar Kompilasi Hukum Islam dalam Tata Hukum Nasional. Jakarta: Gema Insani Press, 1994.

Ali, Zainuddin. Hukum Perdata Islam di Indonesia. Jakarta: Sinar Grafika, 2006.

Bisri, Cik Hasan. Kompilasi Hukum Islam dan Peradilan Agama dalam Sistem Hukum Nasional. Jakarta: Logos, 1999.

Dahlan, Abdul Azis. Ensiklopedi Hukum Islam. Jakarta: P.T. Intermasa, 2003.

Direktori Pembinaan Badan Peradilan Agama Islam Departemen Agama RI. Kompilasi Hukum di Indonesia. Jakarta: Direktori Pembinaan Badan Peradilan Agama Islam Departemen Agama RI, 2001.

al-Fanani, Zainuddin bin Abdul Aziz al-Malibari. Fath al-Mu'in. Semarang: Toha Putra, n.d.

Ghazaly, Abd. Rahman. Fiqih Munakahat: Seri Buku Daras. Jakarta: Prenada Media, 2003.

al-Habsyi, M. Baqir. Fikih Praktis. Bandung: Mizan, 2002.

Hadikusuma, Hilman. Hukum Perkawinan Indonesia Menurut Pandangan Hukum Adat, Hukum Agama. Bandung: Mandar Maju, 1990.

al-Hamdani, H.S.A. Risalah Nikah Hukum Perkawinan Islam. Jakarta: Pustaka Amani, 1989.

al-Hussaini, Imam Taqiyuddin Abu Bakar bin Muhammad. Kifayah al-Akhyar. Beirut: Dar al-Kutub al-'Ilmiyah, n.d.

Kamal, Fahmi. "Perkawinan Adat Jawa dalam Kebudayaan Indonesia", Jurnal Pariwisata dan Budaya 5, no. 2 (2014).

Mawahib, M. Mahdil. Fiqih Munakahah. Kediri: STAIN Kediri, 2009.

Pasaribu, Debora Maria Paramita. "Perkembangan Sistem Perkawinan Adat Batak Toba di Kota Medan", Diponegoro Law Journal 6, no. 2 (2017). 
Pratama, Bayu Ady. "Pernikahan Adat Jawa di Desa Nengahan Kecamatan Bayat Kabupaten Klaten", Jurnal Haluan Sastra Budaya 2, no. (2018).

al-Qaradhawi, Yusuf. Fatwa-fatwa Kontemporer. Jakarta: Gema Insani Press, 1995.

ash-Shiddieqy, Teungku Muhammad Hasbi. Hukum-hukum Fiqih Islam: Tinjauan Antar Mazhab. Semarang: P.T. Pustaka Rizki Putra, 2001.

Syarifuddin, Amir. Hukum Perkawinan Islam di Indonesia: antara Fiqih Munahakat dan Undang-undang Perkawinan. Jakarta: Kencana Prenada Media Group, 2009.

Undang-undang Nomor 1 Tahun 1974 Tentang Perkawinan. az-Zuhaili, Wahbah. Fiqh al-Islami wa Adillatuhu. Beirut: Dar al-Fikr, n.d. 
